\title{
Exploration of Strengthening the Propaganda of Ideological and Political Management Work in Universities by using the Advantages of Network Convergence
}

\author{
Jingru Liu \\ Baicheng Normal University, Baicheng, Jilin, 137000, China \\ email: dongboyongliu@126.com
}

\begin{abstract}
Keywords: University, Undergraduates, the Advantages of Network Convergence, the Propaganda of the Ideological and Political Management Work

Abstract. In recent years, with China's rapid development of information and network technology, the network has penetrated into all aspects of people's life, study and work. In order to adapt to the ideological influence on the undergraduates caused by the massive network information and its rapid spread, it is very necessary to use the advantages of the Internet to strengthen the propaganda of the ideological and political management work in universities.
\end{abstract}

\section{Introduction}

With the widespread application of network technology in our country, the management of ideological and political work in universities will face more challenges and a good opportunity for rapid development. The network world nowadays is filled with many attractions and temptations, it a key problem related to how to effectively occupy network education this position that what kind of attitude university Ideological and political propaganda management departments should take how to deal with these problems. The departments of the ideological and political propaganda management according to their functional advantages, should create and improve the promotion of Ideological and political education management platform, promote and improve the effective network carrier of ideological and political course network teaching platform and students online, show the network aggregation advantage, and strengthen the management of the ideological and political propaganda work effectively.

\section{The Meaning and Advantage of Network Convergence}

Network aggregation refers to take use of manual or machine to select, analyze and strictly classify the network and information resources (such as BBS, blog, video, supply and demand information, documents etc.), giving users a useful, targeted, valuable information. Network aggregation is not simply to gather a large amount of information, but does the careful selection and careful classification after taking more in-depth research and analysis of a large number of information resources, Network aggregation is not simply a large amount of information gathered, is for a large number of information resources to conduct a more in-depth analysis of the study after the careful selection and careful classification, such as the electronic bulletin board system that is BBS. Network aggregation model is often edited carefully selected and strictly classified by manual or machine, as well as additional comments, which are carefully chosen and demanded very high. The advantage of network convergence is to take use of their own advantages to integrate a large number of uninterrupted information resources and achieve the sharing and win-win situation with users.

\section{The Significance and Present Situation of Strengthening Ideological and Political Management in Universities by using the Advantages of Network Convergence}

With the rapid development of China's technology and information technology, network technology 
has integrated into college students' daily and learning life in every corner. Compared with some western countries, China's education informatization is carried out too late, but its development speed should not be underestimated. Like a mighty storm, the network technology has brought the earth shaking change to the university student's life, the study and the way of thinking. It has become the focus to strengthen the ideological and political work in colleges and universities by means of network convergence. The teachers and students in universities are the ones who most frequently use network technology, and the most important feature of the network is open and interactive. Because the network world does not have the border restrictions of the reality, and do not need face to face communication and sharing, that is more conducive to the exchange of ideas between teachers and students, so as to achieve unexpected harvest. Network aggregation just is the collection and sorting, of massive network information resources. Some events may not be the focus of the information under normal conditions, but if they will be shocking in the network environment, due to the aggregation effect of the network, the information has become the focus of public opinion in a short time possibly, and even affects people's life. Therefore, it is very important practical significance to study and explore how to use the advantage of network polymerization to strengthen the management of the ideological and political propaganda work, form the new method of the combination of propaganda ideological work adapted to the development of the characteristics of the times and college students physiological and psychological characteristics. Therefore, taking the use of network aggregation to carry out ideological and political work has become ideas and methods to innovate the ideological and political management work in universities.

At present, for the ideological and political education propaganda work the universities have done the following aspects:

They take the moral education as the main focus, innovate the theory of ideological and political education in the network environment, and carry out the work of ideological and political education production through publicity and supervision of network information.

Based on the characteristics of the network technology, this paper studies and discusses the effectiveness of information dissemination, and uses the display information and manipulation technology to attract the attention of college students.

It can promote the ideological and political education work that integrating and manipulating the entire campus network and strengthening the campus network of cultural construction.

The actual case is studied and explored in the network. Studying and analyzing typical case related with university network Ideological and political education propaganda platform, network publicity and education activities, and guide the network public opinion and network related emergency treatment, which can be prepared for the exploration and practice of the network ideological and political education theory.

Create and apply the ideological and political course network teaching platform. Because the network teaching platform is not bound by space and time, it providing teaching resources of the network course enough for them according to their individual needs and future development needs.

\section{Strengthening the Management of Ideological and Political Work in Universities by using the Advantages of Network Convergence}

In recent years, the construction of campus network in our country is more and more fast, and a lot of financial resources, manpower and material resources will be put into the campus network. With the improvement and development of the campus network construction, the propaganda management work of ideological and political education has entered into the network, which has got a good effect in the early stages because it is a new thing and college students in the spirit of curiosity. After a period of time, there have been some problems affecting the development of the campus network speed and the frequency of use in college students. In order to strengthen the ideological and political management, universities constantly strengthen the campus network construction, and establish a network of Ideological and political education platform. The rapid spread and development of network information resources and the development of the network 
based on the commercial development, to a certain extent, have brought a lot of adverse impact on the management of Ideological and political education. In the network environment, it is important work to be researched and treated in recent times that the ideological and political propaganda management departments how to display its service and management functions, create and use the work system and network carrier by use of polymerization advantage with practical value of the network, with the relative resistance of commercial websites, browsing and learning content broad and rich, and letting students have a strong participation and a desire to learn, rich network moral and psychological education and rich skills wonderful positive guidance of college students network platform, to strengthen the management of the ideological and political propaganda work. And seizing the network education is full of competition, which requires ideological and political propaganda management personnel and teachers in universities to take a serious attitude and professional means to face seriously, and take effective strategies to deal with them. On the contrary, the correct guidance of public opinion to guide the network ideological line will become an empty talk. Ideological and political work in universities must comply with the needs of the development and progress of the times, focusing on the network, from all angles and implementing a comprehensive reform in-depth is an urgent problem to be solved. Thus, the management department of the ideological and political propaganda with the functions of their own advantages, should create and apply the network focus effect by themselves, skillfully take the initiative to play their own advantages on management and service and guiding public opinion positive energy of the network, use the network to gather as a whole inside the university, show the dominance and hold network aggregation advantage to attract all network concerns of the school students to the focus as far as possible, in order to achieve effective positive guidance. That can not only continuous improve and develop the campus network in universities in the ideological and political propaganda management website, but also achieve the integration of resources in a certain range, the form the regional network publicity advantage thought political education management unified education platform, to achieve more extensive effects of inter - school, inter - regional network. At the same time, constantly promoting the effectiveness evaluation of the network to guide public opinion, creating and apply more extensive "Ideological and political education" network teaching platform for college students, to fill the insufficient of communication among students, practical teaching and practical teaching deficiencies, which is conducive to strengthening the management of the ideological and political propaganda work.

In the current era of rapid development of network, the management work of the ideological and political propaganda should be carried out careful investigation, in the network communication platform and take interaction and in-depth exchanges with peer and college students to get the experience of colleagues and understand the change of students' thought and future development trends. Combined with the actual universities, take scientific analysis and research the characteristics and rules of on the management work of the ideological and political propaganda, find out the lack of work, find the right way to deal with and solve strategy according to the information, and bring the network management work of the ideological and political propaganda based on the weight into the daily work.

The university should strengthen the propaganda work of the ideological and political management, we must get rid of the shackles of the traditional thinking, to adapt to the rapid development of the network information age, to enhance the propaganda staff of the ideological and political management of network knowledge and skills, and improve their ideological and political awareness and management level. The propaganda staff of the ideological and political management need comprehensively and in-depth study and grasp the related network technology and information processing knowledge, improve their own overall quality, keep up with the pace of development, profoundly understand and grasp contemporary mainstream ideology and value concept as well as advanced cultural knowledge, and form a master of ideological and political propaganda work of talents, who can skillfully use the Internet and computer operation, clearly understand the situation and future trend of network development, and have strong ability to process information. Through the campus network to promote ideological and political management platform, so that teachers and 
students get rid of time and space constraints, access to ideological and political education, provide a more effective management platform of ideological and political work in universities.

To play the advantages of network convergence to carry out ideological and political work in colleges and universities, the most important thing is to determine the network ideological and political management work objectives. In order to make the network aggregation to achieve the desired educational harvest, we must create a simple and changeable, vivid and intuitive, easy to accept the network information resources. The creation of interesting information resources plays an important role in the management work of political propaganda thought. The artful arrangement of the propaganda platform of Ideological and political education management in university can not only attract students' attention, also get unexpected results. For example, "advanced character story" can be settled in the Ideological and political education management platform, where college students can read about the advanced character of the story and go into the advanced character of the heart to feel the spirit of their selfless dedication, the courage to bear and the courage to innovate in the new era, let students learn new thought, also let them have the advanced character of the ideological influence, so that their overall quality has been further improved. It can be seen that rapid development of the information network in the new era, universities by taking the use of network advantage, using simple and changeable communication means, can quickly achieve the purpose of propaganda work of the ideological and political management, and promote its progress.

The management of the ideological and political propaganda department with the functions of their own advantages, the focus of the network platform self creation and application can be manipulated to show their leadership, management and service advantages, the advantages of the network of public opinion to guide the positive energy, through the network so that university administrators, teachers and students a unified understanding, showing dominance hand network advantage in order to achieve effective, positive guidance. In addition, to achieve the integration of resources promote the ideological and political education in a certain range, the formation of a certain region show the advantage of the unified aggregated network education platform, to maintain its own unique personality characteristics and basic appeal, to achieve cross regional and cross schools, more extensive integration of resources, the formation of more widely network ideological and political propaganda education management system. Using the network polymerization advantage and achieve the integration of resources within the region, the creation of a network of hot social focus and guide signs, to achieve regional management of the ideological and political propaganda work and the network of public opinion is more comprehensive and in-depth personalized trend.

The theory and practice of the implementation of comprehensive quality education for college students in the network information literacy as the focus of the new education under the environment of study and research, to take comprehensive and in-depth education strategy, enhance students' ability to resist the bad network information, so that they can correctly distinguish the network rumors, get rid of the temptation of the network, on the network to participate in interactive communication healthy thought and correct means, more effective use of network information, promote the development of their own health and comprehensive. For newly enrolled college students, to strengthen the cultivation of their ability to distinguish the network information, the pilot work can be carried out in small range on campus, in the pilot process, constantly sum up experience, and gradually improve and perfect, and incorporated into the ideological and political education, every aspect of teaching practice of ideological and moral education and related laws.

Increase investment, according to the actual situation and development trend of network ideological and political education management, and the network of public opinion to guide practical results which carry out the evaluation, formulate the corresponding evaluation criteria, the formation of a scientific and effective network management of the ideological and political propaganda work evaluation system, use scientific and reasonable means of supervision, implementation of supervision and control effective. 


\section{Conclusion}

According to the management of the ideological and political propaganda work, we should strengthen the construction of internal network campus, using the network polymerization advantage, creation and application of some excellent ideological and political education platform, teachers and students interact with the network platform, strengthen interaction and exchange of information and exchange between teachers and students in Colleges and universities between harmonious, equal learning and working environment, strengthen the construction of campus culture and network publicity, strengthening the ability of college students to distinguish network information, identify the correct network rumors, get rid of the temptation of the network, participate in interactive communication on the network with a healthy thought and correct means, more effective use of network information, promote the development of their own health and comprehensive, to achieve the ultimate goal of strengthening the management of the ideological and political propaganda work.

\section{References}

[1] Junjie Liu. Using the advantages of the network to strengthen the propaganda work in Colleges and universities [J]. Chinese and foreign entrepreneurs, 2016,20:165.

[2] Li Meiqing. Exploring the ideological and political management of colleges and universities with the advantage of network convergence [J]. academic forum, 2008,12:179-182.

[3] Ling Fulin, Yang Hanhua. Reflections on Ideological and political work using micro media [J]. news front, 2015,01:172-173.

[4] Zou Lina, Cui Yu, Bai Shun. The use of the network to carry out ideological and political education of College Youth League members to explore [J]. school party building and ideological education, 2015,06:71-72.

[5] Zheng Yupeng. Analysis on the application of network information technology in Ideological and political education in Colleges and universities [J]. China market, 2015,04:70-71.

[6] Liu Xuan, Zhou Q. The "micro era" of College Ideological and political education of micro strategy study of [J]. teaching (Higher Education Forum), 2015,27:56-57.

[7] Ma Jiana. Methods to carry out ideological and political education of college students through the use of new media to explore the [J]. management, 2013,26:243-244. 